\title{
İş SAĞLIĞI VE İŞ GÜVENLİĞİ UYGULAMALARINDA SENSÖR KULLANIMININ İNCELENMESİ
}

\author{
Dr. Öğr. Üyesi Süleyman ŞİMŞEK \\ İstanbul Aydın Üniversitesi, İstanbul \\ suleymansimsek@aydin.edu.tr \\ https://orcid.org/0000-0002-0593-8036 \\ Serkan AĞSEREN \\ İstanbul Aydın Üniversitesi, İstanbul \\ serkan_agseren@hotmail.com \\ Dr. Hatice ŞIMSŞEK \\ Tekirdağ Namık Kemal Üniversitesi \\ h.simsek@nku.edu.tr \\ https://orcid.org/0000-0003-0041-3406
}

\section{ÖZ}

Dünyada ve ülkemizde oluşan iş kazaları incelendiği zaman, kazaların yaklaşık $\% 88$ 'inin "tehlikeli hareket", \%10'unun "tehlikeli durum" ve \%2'sinin de sebebi bilinmeyen durumlardan meydana geldiği görülmektedir. Güvenlik kültürü, tasarımda güvenlik, toplu veya kişisel koruyucu önlemler ile ilgili çalışmalar ülkemizde başlamış ama yeterli seviyeye getirilememiştir. Uzun vadede çalışmalarda, Avrupa standartlarına ulaşılsa dahi, tehlikeli hareketler ile ilgili kazalar, sistematik önlemler almadan yeterli seviyeye getirilemeyecektir. $\mathrm{Bu}$ sistemler çalışanların hatayı yapmayacak veya bazı hatalarını otomatik olarak durduracak şekilde tasarlanmalıdır. İş sağlığı ve güvenliği çalışmalarında dokunmatik sensörler, gaz sensörleri vb. birçok sensör farklı sektörlerde kullanılmaktadır. Ancak ülkemizde ikinci el makine kullanımı çok fazla olduğundan dolayı sensörler etkin olarak kullanılamamaktadır. Eskiden büyük maliyetli olan sensörler günümüz şartlarında çok daha uygun maliyetlerde imal edilmektedir. Çok hızlı şekilde gelişen teknoloji, bu tarz uygulamalara kolaylık sağlamaktadır. Ayrıca endüstri 4.0 ile beraber bu tip kullanımların yaygınlaşacağı öngörülmektedir. $\mathrm{Bu}$ çalışmada $5 \times 5 \mathrm{~L}$ tipi matris yöntemiyle örnek bir vaka incelenerek iş sağlı̆̆ güvenliği değerlendirmeleri yapılmış, kaza sonrası yapılan 
risk analizinde sensörlerin kullanımıyla iş kazası oluşma ihtimali \%75 oranında düşürülmüştür. Zaman içerisinde diğer preslerde ve benzeri makinelerde yapılan uygulamalar vasıtasıyla kazalar minimize edilmiştir.

Anahtar Kelimeler: İ̧ş kazaları, Önlemler, Maliyet, Sensörler

\title{
EVALUATION OF SENSOR IN OCCUPATIONAL HEALTH AND SAFETY APPLICATIONS
}

\begin{abstract}
When work accidents are examined in the world and in Turkey, about $88 \%$ of the accidents occur in "dangerous action" and $10 \%$ occur in "dangerous situation". Studies on safety culture, safety in design, collective or personal protective measures have started in our country, but they have not been brought to sufficient level. In the long term, even if it is reached European standards, accidents related to dangerous actions will not be brought to the adequate level without systematic measures. These systems should be designed to prevent employees from making mistakes or to stop some errors automatically. Studies in occupational health and safety touch sensors, gas sensors, etc. many sensors are used in different industries. However, since the use of second hand machine in our country is too much, sensors are not applied effectively. Large-cost sensors are manufactured at a much more cost-effective cost in today's conditions rather than the past. Quickly developing technology makes it easier for such applications. In addition, this type of use is expected to be widespread with Industry 4.0. In this study, a case study with $5 \times 5$ L type matrix method was examined and occupational health and safety assessments were made, and the risk of occupational accidents was reduced by $75 \%$ by using sensors in the post-accident risk analysis. Accidents have been minimized through applications in other presses and similar machines over time.
\end{abstract}

Keywords: Work accidents, Precautions, Cost, Sensors

\section{GİRİŞ}

Ülkemizde 2012 yılından bu yana yapılan çalışmalar ile iş sağlığı ve güvenliği konusunda farkındalık yaratılmaya çalışılmış, ancak iş kazalarının önüne istenen seviyede geçilememiştir. Kazaların analizinde güvenlik kültürünün yetersiz olması kaynaklı kazaların ön planda olduğu gözlemlenmiştir. Teknolojinin de hızla geliştĭgi günümüzde, alınması gereken önlemler kişinin hata yapmasına olanak vermemesi veya hatasını elimine etmesi üzerine kurulması gerekmektedir. Sensörlerin de genel olarak işleyişi sistemin kişinin inisiyatifinden alınması veya uyarılması üzerine tasarlanmıştır. 
Fiziksel ortam değişikliklerini (1sı, 1şık, basınç, ses, vb.) algılayan elemanlara "sensör" denir (MEB 2012). Başka bir tanımlamada ise sensör, uyarı olarak aldığ1 elektriksel olmayan değerleri elektriksel değerlere dönüştürerek yanıt veren aygit olarak tanımlanır (Yumurtac1 - Yabanova 2018: 201-207). Dijital ve analog olmak üzere 2 çeşit çıkış (sinyal) veren sensör vardır. Sensörler uygulama ve çalışma ortamlarına göre farklılık göstermektedir (Elektrikde 2018). Dijital sinyal, zamana göre değişiklik göstermemektedir. Analog sinyaller ise zamana göre sürekli değiş̧iklik gösterirler. Günümüzde farklı alanlarda sensörler kullanılmaktadır. Asansör kapılarında, merdiven aralarındaki lambalar, otomatik yanan lavabo 1şığ veya su, araç park sensörleri ve bunun gibi birçok sensörü sıralayabiliriz. Bunun yanı sıra birçok farklı tip sensör de bulunmaktadır (Şimşek - Şimşek - Titirinli - Özel 2018: 2268-2268).

Gaz sensörü veya detektörü belirli bir ortamda gaz kaçağını belirler. Renk sensörleri farklı renkleri birbirleri arasında ayırt edebilme özelliğine sahiptir. Kalite kontrol sistemleri, paketleme sistemlerinde kullanılır. Optik bir görüntü almak için görüntü sensörleri kullanılır. Fabrikalarda gaz ve sıvı basınc1, biyomedikal cihazlar, cep telefonu ve elektronik terazilerde yük ölçümünde kullanılır. Fotoelektrik sensörler otomatik kapı, otomotiv endüstrisi, makine sektörü, depolama ve konveyör sistemlerine ve paketleme uygulamalarında kullanılır. Titreşim sensörleri ise belirli bir alandaki hafif vuruş ve titreşimleri algılamada kullanılır. En yaygın olarak araç alarm ve güvenlik sistemlerinde görülür. Algılama özelliklerine göre tipleri olan hareket sensörleridir (Elektrikde 2018). Kızılötesi sensör teknolojisi savunma sanayi, enerji sektörü özellikle sağl1k alanında uygulamalara sahiptir (Altın - Demirel 2016: 1-16). Ortam havasının nem miktarını ölçen cihazlarda kullanılan algılayıcılar, bağıl nem, yaş termometre sıcaklığ 1 , özgül nem ve çiğlenme noktası sıcaklığ gibi farklı fiziksel özelliklere karşı hassasiyete sahiptirler. Bu hassasiyetten dolayı nem ölçüm cihazları kullanılır (Alıç - Kaşka - Bor 2019: 8-16). Her türlü fiziki kuvvet ve basınç değişimini algılayan ve bu değişimi elektriksel sinyale çeviren elemanlara basınç sensörü denir (Işık 2013). Dokunmatik sensörler fiziksel temasla uyarıldığında dokunmatik güvenlik kontrol donanımları, tehlikeli hareketleri durdurur. $\mathrm{Bu}$ tarz sensörler güvenlik kenarları koruma kapılarında, kaldırma tabla ve platformlarında, hareketli depo raflarında, çalışan işlem tablalarında, depolama asansörlerinde, asansör kapılarında, yükleme rampalarında, kaldırma ve devirme donanımlarında veya endüstriyel kapılarda uygulanabilen ezilme ve yırtılmalara karşı koruyucu önlem olarak tasarlanmışlardır (www.schmersal.net). 


\section{KAZA ÍSTATISTIKLERİ}

İş kazaları tüm dünyada olduğu gibi ülkemizde de en önemli ölüm nedenleri arasında yer almaktadır. Bu kazaların ölüm, yaralanma ya da hastalık, üretim kaybı, makine ve ekipmana verdiği zarar gibi sosyal ve ekonomik olmak üzere ülkelere yansıyan pek çok maliyeti bulunmaktadır. Bu maliyetlerin önlenmesi, kazalara neden olan faktörlerin azaltılması ya da tamamen ortadan kaldırılması ile mümkün olmaktadır (Naghavi K - Mortazavi - Asilian M - Hajizadeh 2019: 1-9). Bilimsel ve teknolojik gelişmeler, aynı zamanda bu tehlikelerin önlenmesi konusunda yeni imkânlar da sunmaktadır. Bu bakımdan, iş kazaları ve meslek hastalıkları olarak ifade ettiğimiz bu tehlikeler, çalışanlar ve işyerleri için bir kader değildir. İş sağlığı ve güvenliği ekonomik boyutları bir yana sosyal boyutları itibariyle de ülke kalkınması açısından hayati öneme haiz toplumsal bir olgudur (Şimsek - Saygın - Şimsek - Özel 2018: 1397-1404). Sağliklı ve güvenli bir işyeri ortamı daha verimli çalışmanın ön koşuludur ve özellikle gelişmekte olan ülkelerde toplumsal kalkınmanın belirleyici unsurları arasında yer almaktadır (Ceylan 2011: 18-24).

Uluslararası bazda kaza nedenleri teorilerinin öncüsü kabul edilen Heinrich (1959), teoride kazalara, insan ve makine ilişkisi ile ortaya çıan güvensiz hareket ve davranışların neden olduğunu ortaya koymuştur. Araştırmada kazaların \%88'inin güvensiz davranış; \%10'unun güvensiz ortam; \%2'sinin de önlenemez durumlardan kaynaklandığ 1 ortaya koyulmuştur. Amerika'da National Safety Council Committee'nin yapmış olduğu bir diğer araştırmada, iş kazalarının \%18'inin makine kaynaklı \%19'unun insan kaynaklı \%63'ünün bu iki kaynağın bileşkesinin etkisiyle meydana geldiğini tespit etmiştir.

Çalışma ve Sosyal Güvenlik Eğitim ve Araştırma Merkezi (ÇASGEM) yayınında bahsedilen, Haksöz 1985 Makine Kimya Endüstrisinde yapmış olduğu araştırma da kazaların \%95'inin güvensiz davranış ve kişisel koruyucu donanımın kullanılmamasından; \%5'inin ise teknik nedenlerden kaynaklandığı tespit edilmiştir. Ulusal ve uluslararası alanda yapılan pek çok araştırma, iş kazalarının en çok insan kaynaklı olarak meydana geldiğini ortaya koymuştur (ÇASGEM 2017). Avrupa'daki örnekler incelendiğinde de tehlikeli hareketlere, teknik önlemlerden daha fazla odaklandığı görülmektedir. Bu çalışmaların sonucu tehlikeli durumların önemsiz olması değil, çalışmalarda insanın her zaman hata yapma olasıllğı düşünülmesi gerektiğini göstermektedir. 


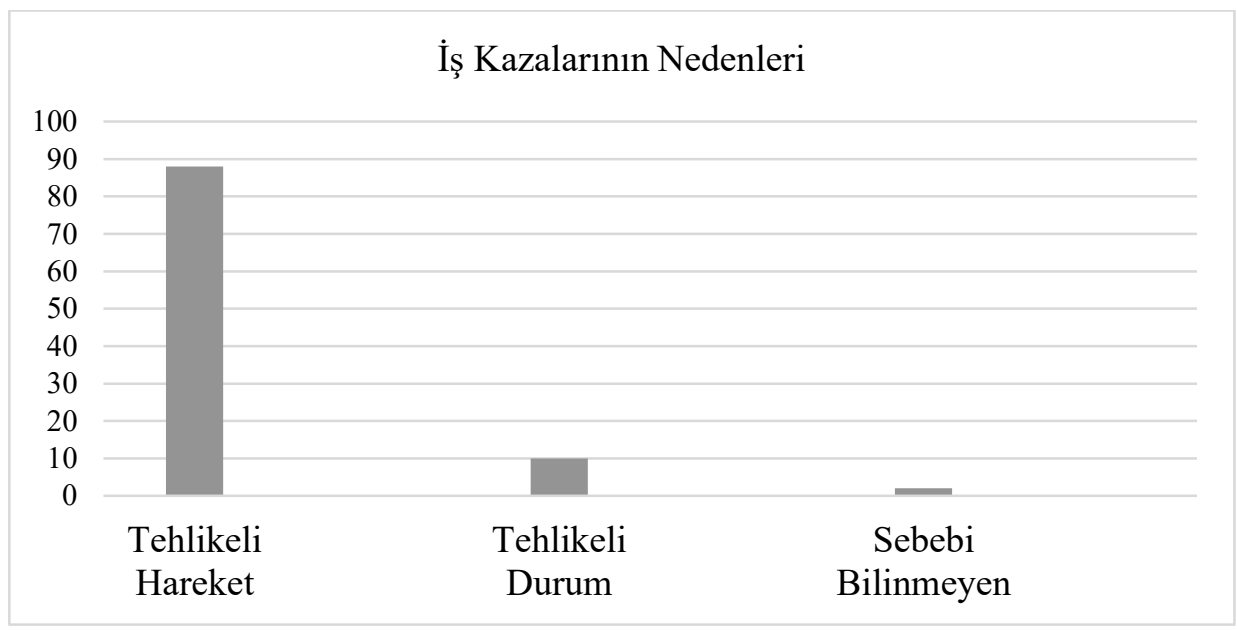

Şekil 1: İş kazalarının Nedenleri (ÇASGEM 2017).

Tehlikeli hareketler, insanların yaratılışından kaynaklı olabileceği gibi kültürel, çevresel, toplumsal vb. birçok faktörden meydana gelebilir. Tehlikeli hareketlere örnek vermek gerekirse; emniyetsiz vaziyet alma, tehlikeli yerlerde çalı̧ma, şaşırma, kızgınlık, üzgünlük, telaş, şakalaşma, kkd kullanmama, talimatlara uymama, gereksiz hızlı çalışma, emniyetsiz yükleme, taşıma, istifleme, emniyet donanımını kullanılamaz duruma sokma, iş makinelerinin karşılaştığı ve şahısların bulunduğu yerlerde hızın azaltılmaması, iş makinelerinin birbirlerini geçmeye çalışması, boomlu iş makinelerinde yükün askıda bekletilmesi, manevracıların şoför veya operatörü görmeden veya anlaş1ır şekilde işaret vermeden manevra yaptırması, bakım kurallarına riayet etmemek, manevracıların iş makinelerinin tesir sahası içerisine görevi olmayan izinsiz kişilerin girmesini engellememesi vb. siralayabiliriz.

Tablo 1 incelendiği zaman eski yıllara göre artışlar gözlenmiş ancak bunun nedeninin online Sosyal Güvenlik Kurumu (SGK) bildirim yapılması olduğu tespit edilmiştir. 
Tablo 1. İş Kazası Geçirenler ile İş Kazası Sonucu Ölenlerin Yaranın Türüne Göre Dağılımı (www.sgk.gov.tr).

\begin{tabular}{|l|c|c|c|c|c|c|}
\hline \multicolumn{1}{|c|}{ Yara Türüi } & \multicolumn{2}{|c|}{2013} & \multicolumn{2}{c|}{2014} & \multicolumn{2}{c|}{2015} \\
\cline { 2 - 7 } & $\begin{array}{c}\text { Kaza } \\
\text { Sayısı }\end{array}$ & $\begin{array}{c}\text { Ölüm } \\
\text { Sayısı }\end{array}$ & $\begin{array}{c}\text { Kaza } \\
\text { Sayısı }\end{array}$ & $\begin{array}{c}\text { Ölüm } \\
\text { Sayısı }\end{array}$ & $\begin{array}{c}\text { Kaza } \\
\text { Sayısı }\end{array}$ & $\begin{array}{c}\text { Ölüm } \\
\text { Sayısı }\end{array}$ \\
\hline $\begin{array}{l}\text { Yaranın türü } \\
\text { bilinmeyen }\end{array}$ & 9459 & 208 & 10697 & 270 & 11232 & 215 \\
\hline $\begin{array}{l}\text { Yaralar ve yüzeysel } \\
\text { yaralanmalar }\end{array}$ & 85469 & 34 & 101158 & 40 & 112397 & 46 \\
\hline Kemik kırıkları & 16172 & 72 & 17202 & 54 & 18131 & 51 \\
\hline $\begin{array}{l}\text { Çıkıklar, burkulmalar } \\
\text { ve incinmeler }\end{array}$ & 27305 & 3 & 31571 & 5 & 35858 & 6 \\
\hline $\begin{array}{l}\text { Travma sonucu organ } \\
\text { kaybı (bedenin bir } \\
\text { parçasının kaybı) }\end{array}$ & 561 & 19 & 570 & 16 & 532 & 13 \\
\hline $\begin{array}{l}\text { Beyin sarsıntısı ve iç } \\
\text { yaralanmalar }\end{array}$ & 924 & 229 & 895 & 194 & 920 & 144 \\
\hline $\begin{array}{l}\text { Yanıklar, kaynar su ile } \\
\text { kavrulma ve donmalar }\end{array}$ & 4794 & 28 & 5626 & 22 & 6277 & 22 \\
\hline $\begin{array}{l}\text { Zehirlenme ve } \\
\text { enfeksiyonlar }\end{array}$ & 1857 & 17 & 4075 & 304 & 2450 & 14 \\
\hline $\begin{array}{l}\text { Suda boğulma ve } \\
\text { nefesin kesilmesi }\end{array}$ & 59 & 28 & 41 & 17 & 55 & 19 \\
\hline $\begin{array}{l}\text { Ses, titreşim ve basınç } \\
\text { etkileri }\end{array}$ & 98 & 2 & 144 & 2 & 182 & 3 \\
\hline $\begin{array}{l}\text { Aşırı ISı, Işı ve } \\
\text { radyasyon etkileri }\end{array}$ & 113 & 3 & 139 & 0 & 137 & 0 \\
\hline $\begin{array}{l}\text { Şok } \\
\text { Birden fazla sayıda } \\
\text { yaralanmalar }\end{array}$ & 1242 & 183 & 133 & 157 & 1367 & 204 \\
\hline $\begin{array}{l}\text { Diğer başlıklar altında } \\
\text { içerilmeyen diğer } \\
\text { belirtilmiş }\end{array}$ & 42876 & 573 & 47389 & 535 & 51432 & 505 \\
\hline
\end{tabular}


Şekil 2'de yaranın vücuttaki yerine göre iş kazalarının dağılım grafiği gösterilmektedir. Grafikte görüldügü gïi el-parmak-bilek kazaları sıkça rastlanılmaktadır. Bilhassa bu ve bunun gibi kazalar sensörler vasitasıyla kolaylıkla minimize edilebilirler.

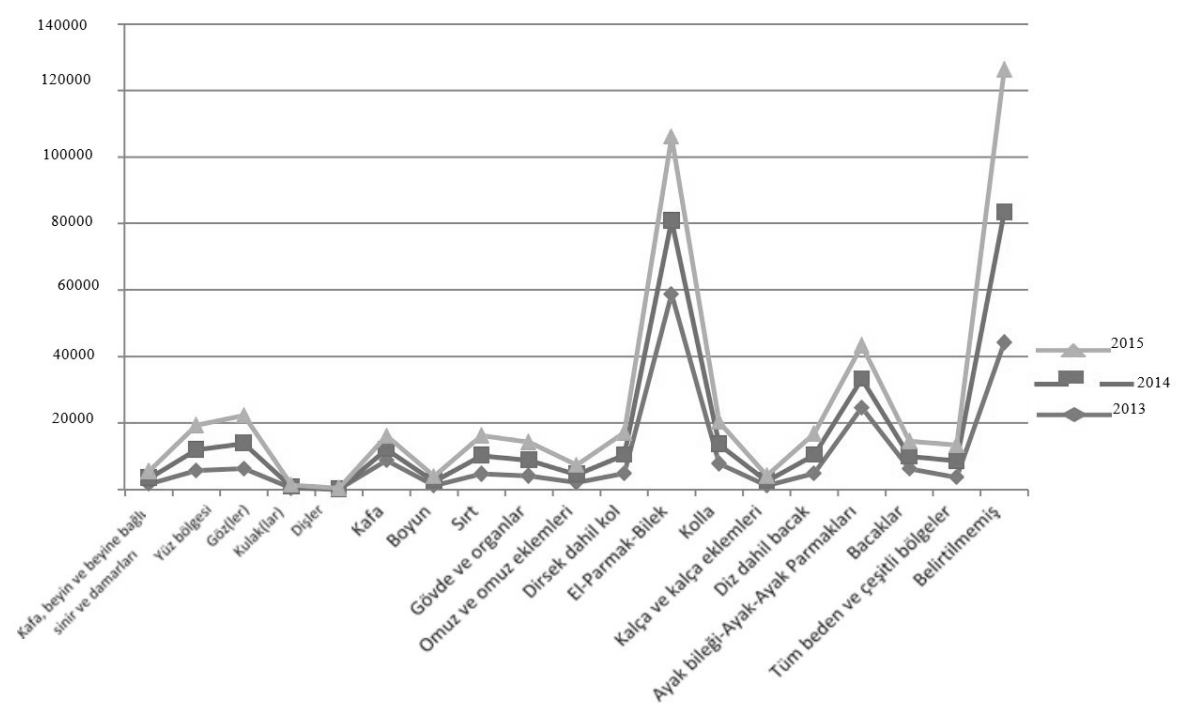

Şekil 2: İş Kazası Sonucu Ölenlerin Yaranın Türüne Göre Dağılımı (www.sgk. gov.tr).

\section{VAKA ÇALIȘMASI}

İncelenen çalışmada, bir otomotiv yan sanayi işletmesinde raporlanan iş kazası analiz edilerek değerlendirilmiştir. Değerlendirme sonucunda, sonuçlar kısmında öneriler verilmiştir.

\section{Vakanın Gelişimi}

Firma beyaz eşya ve otomotiv sektörüne izolasyon malzemesi üretmektedir. Kazanın yaşandığı makine hidrolik prestir. Hidrolik presin arka bölümüne, tasarım sonrası hammaddenin, presin kesim bölümüne rahatça ulaşması için merdane koyulmuştur. Bu sayede bant üzerinden hareket etmeyen malzemeye daha kolaylıkla hareket sağlanmıştır. Üretim arkadan rulo malzemenin beslenip, ön tarafta kalıplar yardımıyla kesilmesi şeklindedir. Gündüz vardiyasında hidrolik preste, önde 2 arkada 1 personel çalışmaktadır. 37 yaşında B.H. isimli operatör, arka bölümde, yeni hammaddeyi makineye bağladıktan sonra ön tarafta bulunan operatörlerle sohbet esnasinda saat 10:22' de elini merdanenin arasına kaptırmıştır. Hemen acil durum telini kendisi çekmiştir. Olayı gören diğer personeller kanamanın durması için sargılı bezle baskı yapmışlardır. Personel 
araç ile hastaneye taşınmıştır. Elin bütünlügü bozulmamış ancak sinirleri hasara uğramış, kolunda kırık ve deformasyon oluşmuştur. Mikro cerrahi yardımıyla ameliyat yapılmış akabinde fizik tedavi süreci başlatılmıştır. Kaza sonrası, personel 6 ay geçici iş göremezlik raporu almış, rapor sonrası sağlıklı bir şekilde iş hayatına devam etmiştir. 6 aydan sonra 1 yıl boyunca fizik tedavi görmüştür.

\section{Vakanın Gelişimi}

Kaza yaşandıktan sonra ilk olarak risk analizi yapılmış, risk analizi doğrultusunda çalışmalar yürütülmüş. Risk analizleri sonucunda merdanenin olduğu bölgeye 1şı1k perdesi koyulmuştur. Risk değerlendirmede L Tipi Matris (5x5 Diyagramı kullanılmıştır). $\mathrm{Bu}$ metot ile öncelikle bir olayın gerçekleşme ihtimali ile gerçekleşmesi takdirinde sonucunun derecelendirilmesi ve ölçümü yapılır.

Tablo 2. Bir Olayın Gerçekleşme İhtimali

\begin{tabular}{|l|c|}
\hline \multicolumn{1}{|c|}{ Olasılık } & $\begin{array}{c}\text { Ortaya çıkma olasılığı için derecelendirme } \\
\text { basamakları }\end{array}$ \\
\hline 1. Yılda bir & Çok küçük olasılık \\
\hline 2. Üç ile altı ayda bir & Küçük olasıllı \\
\hline 3. Ayda bir & Orta dereceli olasılık \\
\hline 4. Haftada bir & Yüksek olasılık \\
\hline 5. Her gün & Çok yüksek olasılık \\
\hline
\end{tabular}

Tablo 3. Bir Olayın Gerçekleştiği Takdirde Şiddeti

\begin{tabular}{|l|l|}
\hline \multicolumn{1}{|c|}{ Şiddet } & \multicolumn{1}{c|}{ Açıklama } \\
\hline 1. Çok Hafif & $\begin{array}{l}\text { Hasar ya da yaralanmaya neden olmayan kaza, iş saati kaybı } \\
\text { olmayan }\end{array}$ \\
\hline 2. Hafif & İlkyardım gerektiren küçük yaralanmalar, tamiratlı maddi hasar \\
\hline 3. Orta & En az üç gün istirahat gerektiren yaralanmalar, maddi hasar \\
\hline 4. Ciddi & Ciddi yaralanma, meslek hastalığı, büyük maddi hasar \\
\hline 5. Çok Ciddi & $\begin{array}{l}\text { Birden çok ölümlü, ölümlü veya sürekli iş göremezlik, çok } \\
\text { büyük maddi hasar }\end{array}$ \\
\hline
\end{tabular}


Tablo 4. Risk Skor Matrisi (Olasılık x Şiddet).

\begin{tabular}{|l|c|c|c|c|c|}
\hline & \multicolumn{5}{|c|}{ ŞiDDET } \\
\hline İHTiMAL & $\begin{array}{c}1 \text { (Çok } \\
\text { Hafif) }\end{array}$ & 2 (Hafif) & $\begin{array}{c}3 \text { (Orta } \\
\text { Derece) }\end{array}$ & 4 (Ciddi) & $\begin{array}{c}5 \text { (Çok } \\
\text { Ciddi) }\end{array}$ \\
\hline 1 (Çok & Anlamsız & Düşük & Düşük & Düşük & Düşük \\
Küük) & 1 & 2 & 3 & 4 & 5 \\
\hline 2 (Küçük) & Düşük & Düşük & Düşük & Orta & Orta \\
\hline 3 (Orta & 2 & 4 & 6 & 8 & 10 \\
Derece) & Düşük & Düşük & Orta & Orta & Yüksek \\
\hline 4 (Yüksek) & Düşük & Orta & Orta & Yüksek & Yüksek \\
\hline 5 (Çok & 4 & 8 & 12 & 16 & 20 \\
Yüksek) & Düşük & Orta & Yüksek & Yüksek & Yüksek \\
\hline
\end{tabular}

Tablo 5. Risk Skor Matrisi (Olasılık x Şiddet).

\begin{tabular}{|l|l|}
\hline \multicolumn{1}{|c|}{ Sonuç } & \multicolumn{1}{|c|}{ Eylem } \\
\hline $\begin{array}{l}\text { Önemli Riskler } \\
(15.16 .20 .25)\end{array}$ & $\begin{array}{l}\text { Belirlenen risk azaltılıncaya kadar iş } \\
\text { başlatılmamalı eğer devam eden bir } \\
\text { faaliyet varsa derhal durdurulmalıdır. } \\
\text { Risk işin devam etmesi ile ilgiliyse acil } \\
\text { önlem alınmalı bu önlemler sonucunda } \\
\text { faaliyetin devamına karar verilmelidir. }\end{array}$ \\
\hline Orta Düzeydeki Riskler (8.9.10.12) & $\begin{array}{l}\text { Belirlenen riskleri düşürmek için } \\
\text { faaliyetler başlatılmalıdır. Risk azaltma } \\
\text { önlemleri zaman alabilir. }\end{array}$ \\
\hline Katlanılabilir Riskler (2.3.4.5.6) & $\begin{array}{l}\text { Belirlenen riskleri ortadan kaldırmak } \\
\text { için ilave kontrol proseslerine ihtiyaç } \\
\text { olmayabilir. Ancak mevcut kontroller } \\
\text { sürdürülmeli ve bu kontrollerin } \\
\text { sürdürüldüğü denetlenmelidir. }\end{array}$ \\
\hline Önemsiz Riskler (1) & $\begin{array}{l}\text { Belirlenen riskleri ortadan kaldırmak } \\
\text { için kontrol prosesleri planlamaya ve } \\
\text { gerçekleştirilecek faaliyetlerin kayıtlarını }\end{array}$ \\
& saklamaya gerek olmayabilir. \\
\hline
\end{tabular}


Ölçeğin Türkçe versiyonunun güvenilirliğini ölçmek amacıyla her bir soru için Risk analizinde yukarıdaki tablolardan elde edilen değerler risk değerlendirme formuna kaydedilir (Şekil 3.) ve belirtilen eylemlere göre en büyük değerden başlayarak riskler için gerekli önlemler alınır. Alınması gereken önlemlerin eksiksiz olarak uygulanması halinde zarar derecesi düşer ve yeni duruma göre kontrol edilmiş risk değeri tespit edilmiş olur (Özkiliç 2005). Örnekte, kaza sonrası risk analizi yapılmış, risk sonucu önemli risk olarak değerlendirilmiştir.

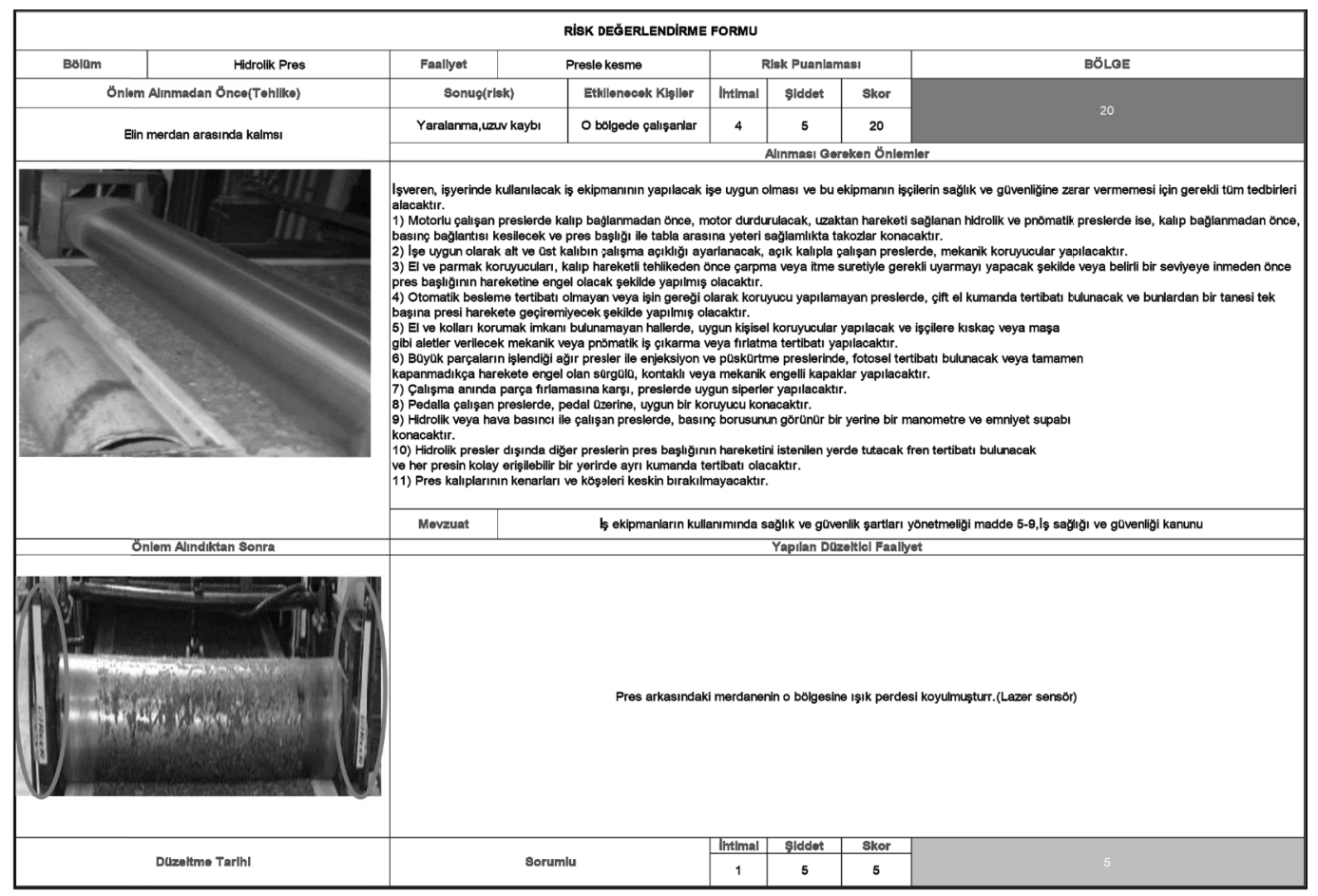

Şekil 3: Risk Değerlendirme Formu.

Tablo 6'da iş kazasının maliyet hesapları bulunmaktadır. Alınan önlemdeki ışık perdesi sensörü maliyeti ise 1500-3000 TL arasındadır. Aslında iş kazasında oluşan maliyet ile fabrikadaki tüm bölgelere 1şı perdesi koyulabilirdi. Ayrıca bu kaza maliyetinde, hesaplanamayan veya hesaplanması çok zor olan maliyetler de bulunmaktadır (Üretim kaybının maliyeti, Çalışanların kazadan dolayı korku veya psikolojik nedenlerle üretimde meydana gelen verim kaybının maliyeti, kaza nedeniyle üretimde oluşan kalite bozukluğunun maliyeti vb.). 
Tablo 6. İş Kazası Maliyeti.

\begin{tabular}{|c|c|}
\hline \multicolumn{2}{|c|}{ Direk Maliyetler-Toplam Kayıp Gün 180 Gün } \\
\hline İlkyardım masrafları & 1000 も \\
\hline Tedavi için işverenin harcadığı para & 15000 も \\
\hline Tamir için harcanan masraf & $500 も$ \\
\hline Ara Toplam & $16500 も$ \\
\hline \multicolumn{2}{|l|}{ Endirekt Maliyetler } \\
\hline $\begin{array}{l}\text { Kazaya uğrayan işçinin ve birlikte çalıştığ işçilerin, } \\
\text { iş başı yaptıktan sonra verimlerinin düşmesi ile ilgili } \\
\text { maliyeti }\end{array}$ & $25000 €$ \\
\hline $\begin{array}{l}\text { Kazaya uğrayan işçi yüzünden; birlikte çalıştığ } 1 \\
\text { işçilerin kaza nedeniyle çalışamadıkları iş süreleri için } \\
\text { ödenen ücretlerin maliyeti }\end{array}$ & 8400 も \\
\hline $\begin{array}{l}\text { Kazada hasara uğrayan tesis, malzeme ve ekipmanın } \\
\text { onarım ve bakımına yönelik maliyeti }\end{array}$ & 4500 も \\
\hline $\begin{array}{l}\text { Kaza geçiren işçi yerine alınan işçinin öğrenme } \\
\text { süresinin maliyeti }\end{array}$ & 300 も \\
\hline Toplam & 54700 も \\
\hline
\end{tabular}

Bunun yanı sıra daha önemli olan insan merkezinde düşünüldüğünde, iş kazası yaşandığında oluşan vicdani rahatsızlık, diğer çalışanlarda oluşan moral bozukluğu, sağlık problemleri, sosyal ve toplumsal sorunlar gibi birçok konuyu beraberinde getirir.

\section{SONUÇ}

Ülkemizde iş sağlı̆̆1 ve iş güvenliği çalışmalarında yasal açıdan Avrupa direktiflerinin bire bir çevrildiğini, uygulama kısmında ise bu yasaların birçoğunun uygulanmadığını veya uygulanamadığı görmekteyiz. Aslında yasal mevzuat konusunda birçok gelişmiş ülkeyle aynı düzeyde olmamıza rağmen, maalesef uygulamada birçok az gelişmiş ülkeyle aynı seviyedeyiz. Makaledeki vaka incelemesinde de görüldügü gibi önlemler teknik olarak yapılabilirliği olan hatta birçoğu maliyet dahi getirmeyen önlemlerdir. Bilhassa ikinci el makinelerde verim düşmesinden çekinen işverenler konuya yeterince önem vermemektedir. Aslında yeni uygulamalar ve sensörler vasıtasıyla verimin daha artacağı projeleri 
yapmak eskiye oranlar çok kolaylaşmıştır. Bu noktada devlet, çalışan, uzman, imalatçılar ve işverenlere büyük görevler düşmektedir. Endüstri 4.0 konusunda her sektörde olduğu gibi iş güvenliğinde de yakalamak zorundayız. Konuyu sadece istatistiksel olarak bakarsak kayıt dışı çalışmalar, bildirim yapılmayan kazalar değerlendirmeleri yanlış yöne götürürler. Sıfır kaza prensibini her sektörde, her işte oluşturmadıkça istenen sonuçlar alınamayacaktır.

2012 yılından bu yana yapılan çalışmalar ve ülkemizde sanayinin gelişimi yıllarından bu yana yapılan çalışmalarda belirli oranlarda farkındalık sağlansa da güvenlik kültürü yeterli seviyeye getirilmedikçe ve önlemler sistematik hale getirilmedikçe iş sağlığ 1 ve iş güvenliği çalışmalarında istenen durum sağlanamayacaktır. Bu yüzden İş sağlığı ve iş güvenliği uygulamalarında farklı bir perspektiften olaylara bakma zorunluluğu kaçınılmaz bir hal almıştır.

Önlemler kişilerin inisiyatifine bırakılmamalıdır. Endüstri 4.0 uygulamaları ile ilgili ARGE çalışmaları yapılmalıdır. Yazılıma önem verilmelidir. Sensörlerle yazılım çalışmaları entegre edilmelidir. Makinelerin tüm bölgelerinde koruyucu çalışmaları düşünülmelidir. TÜBITTAK, KOSGEB vb. kuruluşlar konu hakkında destek ve teşvik çalışmaları yapmalıdır. Sensörlerin bakım, kontrol periyotları belirlenmelidir. Üniversitelerle, devlet iştirakleri arasında ortak projeler çalışılmalıdır. Konu ile ilgili çalıştaylar yapılarak diğer firmalar da bilgilendirilmelidir. İş sağlığı ve güvenliği uzman eğitimlerinde yeni teknolojilerle ilgili eğitimler verilmelidir. İş güvenliği uzmanları araştırmacı olmalı, işverenlere yeni teknolojiler hakkında sunumlar yapabilmelidir. Her ekipmanın da bakım ve kontrol periyotları belirlenmelidir İş ekipmanların kullanımında sağlık ve güvenlik şartları yönetmeliğine sensörler ilave edilmelidir Güvenlik kültürü küçük yaşlarda okullarda verilmesi gerekmektedir. Tasarım ve işletme risk analizleri muhakkak yapılmalıdır. Yurtdışında yapılan sensör çalışmaları incelenmelidir. İş sağlığ1 ve güvenliğinin temelinde insan merkezli yaklaşım unutulmamalıdır. Tüm planlamalar ve tasarımlar bu doğrultuda yapılmalıdır. 


\section{KAYNAKÇA}

Alıç, E., Kaşka, Ö., \& Bor, O. (2019) "Nem ölçerlerin endüstrideki yeri”" Teknik Bilimler Dergisi, 9(1), 8-16.

Altın, E., \& Demirel, S. (2016) "Kizil ötesi sensörlerin sağlik alanindaki uygulamalari” İnönü Üniversitesi Sağlık Hizmetleri Meslek Yüksek Okulu Dergisi, 4(2), 1-16.

Ceylan, H. (2011) “Türkiye'deki iş kazalarının genel görünümü ve gelişmiş ülkelerle klyaslanması" Uluslararası Mühendislik Araştırma ve Geliştirme Dergisi, 3(2), 18-24.

ÇASGEM. (2017), Türkiye'de iş sağllğı ve güvenliği algısı. Ankara: Çalışma ve Sosyal Güvenlik Eğitim ve Araştırma Merkezi.

Elektrikde. (2018), Sensör nedir? Sensörlerin kullanım alanlarına göre çeşitleri. www.elektrikde.com/sensor-nedir-sensorlerin-kullanim-alanlarina-gore-cesitleri (Erişim tarihi: 30.04.2019).

Işık, A. F. (2013), Sensör çeşitleri, robotik alanda kullanılan sensörler ve FSR sensör uygulaması, Balıkesir:Balıkesir Üniversitesi Fen Bilimleri Enstitüsü, (Yayınlanmamış Doktora Tezi).

MEB. (2012), Sensörler ve transdüserler. Ankara: Millî Eğitim Bakanlığ1.

Naghavi K, Z., Mortazavi, S. B., Asilian M, H., \& Hajizadeh, E. (2019) "Exploring the Contributory Factors of Confined Space Accidents Using Accident Investigation Reports and Semistructured Interviews" Safety and Health at Work, $1-9$.

Özkiliç, Ö. (2005), İş Sağliği ve Güvenliği, Yönetim Sistemleri ve Risk Değerlendirme Metodolojileri. Ankara: TISKK Yayınları.

Şimsek, H., Saygın, H., Şimsek, S., \& Özel, K. (2018) “At Energy Transport Lines Occupational Health And Safety Practices And its Evaluatıon" 4th Anatolian Energy Symposium with International Participation, 196, 1397-1404.

Şimşek, S., Şimşek, H., Titirinli, E., \& Özel, K. (2018) “Elektrikli çalışmalarda iş sağlığl ve güvenliği uygulamaları” 4. Anadolu Enerji Sempozyumu, 2268-2268.

www.schmersal.net. (Erişim tarihi: 30.04.2019).

www.sgk.gov.tr. (Erişim tarihi: 30.04.2019).

Yumurtac1, M., \& Yabanova, İ. (2018) "Slvl seviye sensörlerinin incelenmesi ve su seviyesi ölçümü uygulaması" Afyon Kocatepe Üniversitesi Fen Ve Mühendislik Bilimleri Dergisi, 18(1), 201-207. 
